\title{
Attitudes towards Parenthood and Fertility Awareness in Female and Male University Students in South Korea
}

\author{
Hyewon Shin ${ }^{1}$, Jungmin Lee ${ }^{2}$, Shin Jeong Kim ${ }^{3}$, Minjeong $\mathrm{Jo}^{4}$ \\ ${ }^{1}$ Assistant Professor, School of Nursing, Clemson University, South Carolina; ${ }^{2}$ Doctoral Candidate, School of Nursing, University of North Carolina at Greensboro, \\ North Carolina, USA; ${ }^{3}$ Professor, School of Nursing, Hallym University, Chuncheon; ${ }^{4}$ Assistant Professor, College of Nursing, The Catholic University of Korea, \\ Seoul, Korea
}

Purpose: This study investigated intentions and attitudes towards future parenthood and awareness of fertility among university students in South Korea. Methods: The participants comprised 166 female and male undergraduate students enrolled at five universities. A cross-sectional survey was conducted from May to July 2019 using the Korean version of the Fertility Awareness Questionnaire and Attitudes of Parenthood. The data were analyzed using descriptive statistics based on participants' general characteristics, the $\chi^{2}$ test to identify differences in intentions, and the t-test to evaluate attitudes towards parenthood and awareness of fertility in female and male students. Results: Both female and male students desired to have two children, but they lacked awareness about fertility. The possibility of combining work and having children, along with the availability of childcare resources, impacted the desire for parenthood. Male students tended to consider parenthood as less impactful on their lives and careers than female students. Social structures might also impact the decision to have children. Conclusion: It is important to provide health education emphasizing fertility awareness and parenthood in young adulthood so participants can consider these facts in advance. In addition, the government should provide resources for couples making parenthood decisions.

Key words: Awareness; Attitude; Fertility; Intention; Parenting

\section{Corresponding author Minjeong Jo \\ https://orcid.org/0000-0002-1101-4008}

College of Nursing, The Catholic University of Korea,

222 Banpo-daero, Seocho-gu, Seoul 06591, Korea

TEL +82-2-2258-7412 FAX +82-2-532-6537

E-MAIL minjeongjo@catholic.ac.kr

Received Jan 19, 2020 Revised Mar 4, 2020 Accepted Mar 9, 2020 (a) This is an Open Access article distributed under the terms of the Creative Commons Attribution NonCommercial License (http://creativecommons.org/licenses/by-nc/4.0/) which permits unrestricted noncommercial use, distribution, and reproduction in any medium, provided the original work is properly cited.

\section{INTRODUCTION}

\section{Need for Study}

South Korea has the lowest fertility rate of any Organization for Economic Cooperation and Development (OECD) country [1], with a total fertility rate (TFR) of 1.05. The TFR is defined as the number of children born to a woman over the course of her lifetime. Late childbearing patterns worldwide may also have resulted in a lower TFR [2]. In Korea, the average age of mothers who have the first child has increased from 27.2 years in 1998 to 31.9 years in 2018 [3]. This trend for late childbearing could be problematic because declining fertility rates negatively affect the development of society and economic growth for the next generations [4]. University students can be considered the prospective parent generation of the near future in terms of their desire for marriage and parenthood. This is because, in this period, they develop self-identity, mature emotionally, and build intimacy with their partner [5]. Therefore, it is necessary to foster positive values for marriage and childbirth so that university students 
may prepare themselves to fulfill their desired parental role based on their decision.

The tendency to delay childbearing reflects various factors, including perceptions of the value of marriage and children, gender equity, a supportive environment, pursuing educational goals, and securing economic stability [6-8]. Song and colleagues reported that the birth rate was higher among women who had only graduated from high school than among college or university graduates [7]. Korea had the highest proportion of 25- to 34-year-olds who completed a bachelor's degree among OECD countries in 2017. Furthermore, in the last decade, the proportion of young females among 15- to 34year-olds who completed a bachelor's degree increased from $58 \%$ in 2007 to $75 \%$ in 2017 [1]. While women are more educated and more likely to be employed than the past, gender equality in the role of raising and caring for children in Korea remains lower than in Western Europe [9]. Given this context, women's intentions and attitudes toward parenthood may be negatively affected [7].

The young generation's attempts to delay pregnancy until they are ready is a significant factor that may be related to reduced fertility [10]. From the late 20s, woman's fertility starts to decrease, and it decreases rapidly after the age of 37 years. Furthermore, at the time of the birth of the first baby, older mothers are associated with an increased rate of obstetrical complications [11]. Researchers have reported that lack of knowledge about fertility-related topics, such as aging-related infertility and the limitations of assisted reproductive techniques, is particularly evident among university students [12-15]. Previous research findings have pointed out that assessing fertility awareness and providing education for university students is necessary to help them make more informed reproductive decisions [13-15]. However, it is relatively unknown to what extent women and men seeking higher education in Korea are aware of age-related fertility decline.

Although the social participation of the woman workforce in the labor market is prevalent, there still exists social pressure for Korean women to conduct childcare and household tasks while men focus on economic activity [16]. This social and cultural context may impact attitudes toward parenthood and fertility awareness among university students in Korea. Therefore, the purposes of this study were to (1) assess university students' intentions and attitudes towards future parenthood, (2) to evaluate their awareness of fertility, and (3) to compare the differences in these findings, including intentions and attitudes towards parenthood and awareness of fertility, between female and male university students.

\section{METHODS}

\section{Study Design and Sample}

This questionnaire-based study used a cross-sectional and descriptive design. Participants were recruited from five universities located in Seoul, Gyeonggi Province, Gangwon Province, North Jeolla Province, and South Gyeongsang Province in Korea between May and July 2019. The following inclusion criteria were used to identify the sample participants who were eligible for the study. The criteria were: 1) age between 18 (based on the standard of adulthood in the majority of countries) and 30 (based on the report that Koreans' average age of first marriage was 30.4 years old [17], and 2) enrolled in a full bachelor's degree study program at a university. The sample size was calculated using $\mathrm{G}^{*}$ Power version 3.1.9 based on Cohen's sampling formula. The minimum sample size was 145 for the $x^{2}$ test (cross-tabulations) at a significance level of .05 , a power of .90 , and an effect size of .30. We included $15 \%$ more participants considering the possibility of incomplete responses. In total, 166 participants completed the survey, which was a satisfactory sample size.

\section{Data Collection}

All authors contacted the professors and educational staff at each university to obtain their support in identifying potential participants. After gaining consent from university representatives, the researcher or research assistants approached potential eligible students after their classes to assess their eligibility and interest in study participation. Once students had granted permission, the researchers explained the study purposes and procedures, and invited the students to participate in the study. The students completed the survey in a classroom or in a place with privacy near the classroom after providing written consent. The survey was distributed and then collected immediately after being filled out.

\section{Measures}

University students' intentions and attitudes with respect to future parenthood and awareness about fertility were measured using the Korean version of the Fertility Awareness Questionnaire and Attitudes of Parenthood [12]. After obtaining permission from the developer of the questionnaire, the translation into Korean was conducted based on guidelines by DeVellis [18]. The translated questionnaire was pretested with 11 university students (six men and five women). It took 10 to 15 minutes on average to complete the questionnaire and the students reported no difficulties in understanding the item 
contents or responding to the questions. The original questionnaire demonstrated good face validity and established internal consistency (Cronbach's $\alpha>$.70) [12], and it has previously been administered to American, Danish, Hong Kong, and Swedish university students [12-15].

The Korean version of the Fertility Awareness Questionnaire and Attitudes of Parenthood comprised 53 items in the following seven categories: a) sociodemographic (seven items on age, gender, academic grade, discipline, residency, current dating partner, and plan to have children in the future), b) childbearing intentions children (four items), c) importance of having a child (one item), d) presumed behaviors in case of infertility (three items), e) conditions for parenthood (13 items), f) perceived life changes due to the impact of parenthood (16 items), and g) awareness of fertility (nine items). Five experts evaluated the content validity using the item-level content validity index (I-CVI). An I-CVI of more than .78 is considered to indicate good content validity [19]. As the I-CVI of all items was 1.0 in the second validity analysis, the content validity of the measurements used in this study was considered appropriate. The reliability for 'attitudes of parenthood' was shown by a Cronbach's $\alpha$ value of .73, while the Cronbach's $\alpha$ of 'perceived life changes due to the impact of parenthood' was .83 in this study.

\section{Ethical Approval}

The study was approved by the Institutional Review Board of Hallym University in Korea (\#HIRB-2019-072). All participants gave written informed consent and were informed that they could withdraw their consent at any time.

\section{Statistical Analysis}

SPSS Statistics 26 (IBM, Armonk, NY, USA) was used for the statistical analysis. Descriptive statistics including mean, standard deviation, and response frequency were used for the general characteristics. Continuous data from open responses regarding awareness of fertility issues were categorized into age groups or levels of percentages. The correct answers for awareness of fertility were determined based on published data from the Centers for Disease Control and Prevention [20]. The differences in childbearing intention, the importance of having a child, and presumed behaviors in case of infertility were analyzed using the $x^{2}$ test and the t-test. Comparisons were made between female and male university students regarding awareness of fertility, conditions for parenthood, and perceived life changes due to the impact of parenthood using the $x^{2}$ test. The threshold for statistical significance was set at $p<.050$.

\section{RESULTS}

\section{General Characteristics of Participants}

Almost equal proportions were shown for gender, with 85 female students (51.2\%) and 81 male students (48.8\%) (Table 1). The average age of participants was $22.3(\mathrm{SD}=1.7)$ years. Regarding discipline, participants who were majoring in medicine and nursing accounted for the largest proportion $(38.2 \%)$ of participants, followed by those majoring in engineering and education (21.8\%, 21.2\% each), and social sciences $(15.8 \%)$. Participants who had a dating partner at the time of the study accounted for $44.0 \%$ of the sample.

Table 1. General Characteristics of Participants

$(N=166)$

\begin{tabular}{|c|c|c|}
\hline Variable & Categories & $\begin{array}{l}\mathrm{n}(\%) \text { or } \\
\mathrm{M} \pm \mathrm{SD}\end{array}$ \\
\hline \multirow[t]{3}{*}{ Academic grade* } & Sophomore & $3(1.8)$ \\
\hline & Junior & $86(52.5)$ \\
\hline & Senior & $75(45.7)$ \\
\hline Age (year) & & $22.3 \pm 1.7$ \\
\hline \multirow[t]{2}{*}{ Gender } & Man & $81(48.8)$ \\
\hline & Woman & $85(51.2)$ \\
\hline \multirow[t]{5}{*}{ Discipline* } & Social sciences & $26(15.8)$ \\
\hline & Engineering & $36(21.8)$ \\
\hline & Medicine/nursing & $63(38.2)$ \\
\hline & Education & $35(21.2)$ \\
\hline & Arts/physical sciences & $5(3.0)$ \\
\hline \multirow[t]{4}{*}{ Residency } & Alone & $49(29.5)$ \\
\hline & Family (parents or siblings) & $75(45.2)$ \\
\hline & Same-gender friend & $41(24.7)$ \\
\hline & Partner (opposite-sex) & $1(0.6)$ \\
\hline \multirow{2}{*}{$\begin{array}{l}\text { Current dating } \\
\text { partner }\end{array}$} & Yes & $73(44.0)$ \\
\hline & No & $93(56.0)$ \\
\hline \multicolumn{2}{|l|}{$\begin{array}{l}\text { If yes, period of } \\
\text { dating (month) }\end{array}$} & $16.06 \pm 16.64$ \\
\hline \multirow{2}{*}{$\begin{array}{l}\text { Plan to have a child } \\
\text { in the future }\end{array}$} & Yes & 119 (71.7) \\
\hline & No & 47 (28.3) \\
\hline
\end{tabular}

${ }^{*}$ Missing data were not included.

\section{Differences between Genders in Childbearing Inten- tions, Importance of Having a Child, and Presumed Behaviors in Case of Infertility}

Regarding childbearing intentions, $71.7 \%$ of all participants $(n=119)$ responded that they were willing to have children in the future $(69.4 \%$ for women and $74.1 \%$ for men) (Table 2). Among participants who responded that they would like to have children in the future, the average number of children 
Table 2. Childbearing Intentions, Importance of Having a Child, and Presumed Behaviors in Case of Infertility

$(N=166)$

\begin{tabular}{|c|c|c|c|c|c|c|}
\hline \multirow[b]{2}{*}{ Variable } & \multirow[b]{2}{*}{ Categories } & Total & Woman & Man & \multirow[b]{2}{*}{$x^{2}$ or $\mathrm{t}$} & \multirow[b]{2}{*}{$p$} \\
\hline & & $\begin{array}{c}\mathrm{n}(\%) \text { or } \\
\mathrm{M} \pm \mathrm{SD}\end{array}$ & $\begin{array}{c}\mathrm{n}(\%) \text { or } \\
\mathrm{M} \pm \mathrm{SD}\end{array}$ & $\begin{array}{c}\mathrm{n}(\%) \text { or } \\
\mathrm{M} \pm \mathrm{SD}\end{array}$ & & \\
\hline \multirow{2}{*}{ Plan to have a child in the future } & Yes & $119(71.7)$ & $59(69.4)$ & $60(74.1)$ & \multirow[t]{2}{*}{0.44} & \multirow[t]{2}{*}{.505} \\
\hline & No & $47(28.3)$ & $26(30.6)$ & $21(25.9)$ & & \\
\hline Desired number of children & & $2.12 \pm 0.70$ & $2.22 \pm 0.72$ & $2.02 \pm 0.68$ & 1.59 & .115 \\
\hline Desired age for first child (year) & & $30.5 \pm 2.4$ & $29.5 \pm 2.2$ & $31.5 \pm 2.1$ & 4.97 & $<.001$ \\
\hline Desired age for last child (year) & & $34.1 \pm 2.7$ & $33.3 \pm 2.5$ & $35.0 \pm 2.5$ & 3.42 & .001 \\
\hline Importance of having a child & & $6.45 \pm 2.71$ & $6.00 \pm 3.04$ & $6.91 \pm 2.24$ & 2.19 & .030 \\
\hline \multirow{3}{*}{ Presumed behavior in case of infertility } & Undergo IVF & $4.55 \pm 3.33$ & $4.49 \pm 3.37$ & $4.62 \pm 3.32$ & 0.25 & .803 \\
\hline & Adoption & $3.12 \pm 2.65$ & $3.46 \pm 2.75$ & $2.75 \pm 2.50$ & 1.71 & .089 \\
\hline & Choose not to have children & $4.95 \pm 3.06$ & $5.61 \pm 3.08$ & $4.26 \pm 2.90$ & 2.87 & .005 \\
\hline
\end{tabular}

$\mathrm{IVF}=\mathrm{In}$ vitro fertilization.

that they wanted to have was $2.12(\mathrm{SD}=0.70)$. There was no significant difference between genders with respect to the desired number of children $(t=1.59, p=.115)$. The overall age at which participants of both genders desired to have their first child was $30.5(\mathrm{SD}=2.4)$ years; for female students, the average age was $29.5(\mathrm{SD}=2.2)$ years, while it was $31.5(\mathrm{SD}=2.1)$ years for male students. The overall average score of both genders regarding the importance of having children was $6.45(\mathrm{SD}=2.71)$ on a visual analog scale of $0 \sim 10$ points. Of note, man participants had a higher average score $(6.91 ; \mathrm{SD}=2.24)$ than woman participants $(6.00 ; \mathrm{SD}=3.04)$, which was a statistically significant difference $(t=2.19, p=.030)$. Regarding presumed behavior in case of infertility, men indicated that they were more likely to pursue in vitro fertilization (IVF) than women (4.62 \pm 3.32 for male students and 4.49 \pm 3.37 for female students). However, this difference was not statistically significant $(t=0.25, p=.803)$. Moreover, woman respondents were more likely to adopt children than man respondents $(3.46 \pm 2.75$ for female students and $2.75 \pm 2.50$ for male students), but there was no statistical significance between genders $(t=1.71, p=.089)$. In contrast, there was a significant difference by gender in the choice not to have children $(\mathrm{t}=2.87, p=.005)$. Woman respondents were more likely to decide not to have children than man respondents in case of infertility $(5.61 \pm 3.08$ for female students and $4.26 \pm 2.90$ for male students).

\section{Conditions for Parenthood}

The proportions of participants who rated the various items for conditions to have children as 'very important' or 'important' on a 5-point Likert scale are described in Table 3. Of the conditions for parenthood, 'that my work can be combined with having children'(88.2\% for women and $74.1 \%$ for men, $\left.x^{2}=5.48, p=.019\right)$ and 'that I have access to childcare'
(83.5\% for women and 58.0\% for men, $x^{2}=13.13, p<.001$ ) were rated significantly more highly by female students than by male students.

\section{Perceived Life Changes due to the Impact of Parent- hood}

The proportions of participants who perceived various life changes due to the impact of parenthood are summarized in Table 4 . There were several significant gender differences in the categories for perceived life changes due to the impact of parenthood. On the items describing possible positive or negative life changes in relation to parenthood, female students showed significantly higher agreement that they would have less time to devote to work and career $\left(x^{2}=9.48, p=.002\right)$, poorer status in the labor market $\left(x^{2}=9.46, p=.002\right)$, and less freedom $\left(x^{2}=6.89, p=.009\right)$ than male students. In contrast, male students showed significantly higher agreement that their life would be changed and impacted in the context of experiencing new interests in life $\left(x^{2}=9.60, p=.002\right)$, having a stronger relationship with their partner $\left(x^{2}=6.03, p=.014\right)$, becoming a real family $\left(x^{2}=8.67, p=.003\right)$, feeling like a complete man $\left(x^{2}=15.04, p<.001\right)$, everyday life becoming more enjoyable $\left(x^{2}=4.66, p=.031\right)$, and doing what is meaningful in life $\left(x^{2}=\right.$ $9.48, p=.002)$.

\section{Awareness of Fertility}

Table 5 summarizes woman and man participants' awareness of fertility issues. Overall, $38.8 \%$ of women correctly estimated the age of optimal fertility, while a large number of men correctly estimated the age of optimal fertility (62.5\%). Perceptions of the optimal age for fertility showed a significant difference by gender $\left(x^{2}=15.23, p=.002\right)$. Neverthe- 
Table 3. Conditions for Parenthood

$(N=166)$

\begin{tabular}{|c|c|c|c|c|}
\hline \multirow{2}{*}{ Items } & \multirow{2}{*}{$\begin{array}{c}\text { Woman }(\mathrm{n}=85) \\
\mathrm{n}(\%)\end{array}$} & \multirow{2}{*}{$\frac{\operatorname{Man}(\mathrm{n}=81)}{\mathrm{n}(\%)}$} & \multirow{2}{*}{$x^{2}$} & \multirow{2}{*}{$p$} \\
\hline & & & & \\
\hline That I have a partner with whom I can share the responsibility & $82(96.5)$ & $80(98.8)$ & 0.93 & .335 \\
\hline That I feel sufficiently mature & $84(98.8)$ & $77(95.1)$ & 2.01 & .156 \\
\hline That I live in a stable relationship & $81(95.3)$ & $79(97.5)$ & 0.60 & .440 \\
\hline That I want to have children before I am 'too old' & $48(56.5)$ & $52(64.2)$ & 1.03 & .309 \\
\hline That my work can be combined with having children & $75(88.2)$ & $60(74.1)$ & 5.48 & .019 \\
\hline That I have completed my studies & $66(77.6)$ & $63(77.8)$ & 0.00 & .984 \\
\hline That I have advanced in my profession & $37(43.5)$ & $37(45.7)$ & 0.08 & .781 \\
\hline That I have a permanent position & $68(80.0)$ & $60(74.1)$ & 0.83 & .364 \\
\hline That I have access to childcare & $71(83.5)$ & $47(58.0)$ & 13.13 & $<.001$ \\
\hline That I/we have a good economic situation & $82(96.5)$ & $72(88.9)$ & 3.56 & .059 \\
\hline That I/ we have a home that is sufficiently large & $46(54.1)$ & $42(51.9)$ & 0.09 & .770 \\
\hline That my friends have had children or are expecting children & $20(23.5)$ & $24(29.6)$ & 0.79 & .373 \\
\hline $\begin{array}{l}\text { That I have had time to travel and do other things that may be } \\
\text { difficult to do with children }\end{array}$ & $33(38.8)$ & $34(42.0)$ & 0.17 & .679 \\
\hline
\end{tabular}

Table 4. Perceived Life Changes due to the Impact of Parenthood

\begin{tabular}{|c|c|c|c|c|}
\hline \multirow{2}{*}{ Items } & \multirow{2}{*}{$\begin{array}{c}\text { Woman }(\mathrm{n}=85) \\
\mathrm{n}(\%)\end{array}$} & \multirow{2}{*}{$\frac{\operatorname{Man}(\mathrm{n}=81)}{\mathrm{n}(\%)}$} & \multirow{2}{*}{$x^{2}$} & \multirow{2}{*}{$p$} \\
\hline & & & & \\
\hline I will develop as a person & $56(65.9)$ & $59(72.8)$ & 0.94 & .331 \\
\hline Less time to devote to work and a career & $33(38.8)$ & $14(17.3)$ & 9.48 & .002 \\
\hline New interests in life & $48(56.5)$ & $64(79.0)$ & 9.60 & .002 \\
\hline A poorer status in the labor market & $26(30.6)$ & $9(11.1)$ & 9.46 & .002 \\
\hline I will give and receive more love & $65(76.5)$ & $60(74.1)$ & 0.13 & .720 \\
\hline A stronger relationship with my partner & $44(51.8)$ & $57(70.4)$ & 6.03 & .014 \\
\hline Less time for my own interests & $31(36.5)$ & $20(24.7)$ & 2.70 & .100 \\
\hline More contact with my close family & $24(28.2)$ & $33(40.7)$ & 2.88 & .090 \\
\hline That we become a 'real family' & $43(50.6)$ & $59(72.8)$ & 8.67 & .003 \\
\hline Strains on my relationship with my partner & $34(40.0)$ & $26(32.1)$ & 1.12 & .290 \\
\hline Another view on what is important & $58(68.2)$ & $61(75.3)$ & 1.02 & .312 \\
\hline Less freedom & $41(48.2)$ & $23(28.4)$ & 6.89 & .009 \\
\hline Everyday life will be more enjoyable & $33(38.8)$ & $45(55.6)$ & 4.66 & .031 \\
\hline Poorer economy & 15 (17.6) & $16(19.8)$ & 0.12 & .728 \\
\hline That I feel 'complete' as a woman/man & $24(28.2)$ & $47(58.0)$ & 15.04 & $<.001$ \\
\hline That I do the thing that is the meaning of life & $52(61.2)$ & 67 (82.7) & 9.48 & .002 \\
\hline
\end{tabular}


Table 5. Awareness of Fertility

$(N=166)$

\begin{tabular}{|c|c|c|c|c|c|}
\hline \multirow{2}{*}{ Items } & \multirow{2}{*}{$\begin{array}{l}\text { Categories } \\
\text { (year or \%) }\end{array}$} & \multirow{2}{*}{$\frac{\text { Woman }(\mathrm{n}=85)}{\mathrm{n}(\%)}$} & \multirow{2}{*}{$\begin{array}{c}\text { Man }(\mathrm{n}=81) \\
\mathrm{n}(\%)\end{array}$} & \multirow{2}{*}{$x^{2}$} & \multirow{2}{*}{$p$} \\
\hline & & & & & \\
\hline \multirow[t]{4}{*}{ At what age are women the most fertile?* } & $15 \sim 19$ & $3(3.5)$ & $5(6.3)$ & \multirow[t]{4}{*}{15.23} & \multirow[t]{4}{*}{.002} \\
\hline & $20 \sim 24^{\dagger}$ & $33(38.8)$ & $50(62.5)$ & & \\
\hline & $25 \sim 29$ & $49(57.7)$ & $23(28.7)$ & & \\
\hline & $30 \sim 44$ & $0(0.0)$ & $2(2.5)$ & & \\
\hline \multirow{4}{*}{$\begin{array}{l}\text { At what age is there a slight decrease in women's ability } \\
\text { to become pregnant? }\end{array}$} & $15 \sim 24$ & $1(1.2)$ & $0(0.0)$ & \multirow[t]{4}{*}{6.03} & \multirow[t]{4}{*}{.109} \\
\hline & $25 \sim 29^{\dagger}$ & $0(0.0)$ & $4(4.9)$ & & \\
\hline & $30 \sim 34$ & $29(34.1)$ & $32(39.5)$ & & \\
\hline & $35 \sim 39$ & $55(64.7)$ & $45(55.6)$ & & \\
\hline \multirow{4}{*}{$\begin{array}{l}\text { At what age is there a marked decrease in women's } \\
\text { ability to become pregnant?* }\end{array}$} & $25 \sim 34$ & $0(0.0)$ & $0(0.0)$ & \multirow[t]{4}{*}{0.05} & \multirow[t]{4}{*}{.974} \\
\hline & $35 \sim 39^{\dagger}$ & $13(15.5)$ & $12(15.0)$ & & \\
\hline & $40 \sim 44$ & $29(34.5)$ & $29(36.2)$ & & \\
\hline & $45 \sim 60$ & $42(50.0)$ & $39(48.8)$ & & \\
\hline \multirow{4}{*}{$\begin{array}{l}\text { A young woman }(<25 \text { years) and a man have } \\
\text { unprotected intercourse at the time of ovulation - how } \\
\text { high is the chance that she will become pregnant?* }\end{array}$} & $0 \sim 29$ & $4(4.8)$ & $16(19.8)$ & \multirow[t]{4}{*}{17.61} & \multirow[t]{4}{*}{.001} \\
\hline & $30 \sim 39^{\dagger}$ & $9(10.7)$ & $19(23.4)$ & & \\
\hline & $40 \sim 49$ & $17(20.2)$ & $16(19.8)$ & & \\
\hline & $50 \sim 100$ & $54(64.3)$ & $30(37.0)$ & & \\
\hline \multirow{4}{*}{$\begin{array}{l}\text { A woman and a man regularly have unprotected } \\
\text { intercourse during a period of } 1 \text { year: } \\
\text { a) How high is the chance that the women will become } \\
\text { pregnant if she is } 25 \sim 30 \text { years old? }\end{array}$} & $0 \sim 69$ & $3(3.5)$ & $9(11.1)$ & \multirow[t]{4}{*}{7.15} & \multirow[t]{4}{*}{.067} \\
\hline & $70 \sim 79^{\dagger}$ & $18(21.2)$ & $18(22.2)$ & & \\
\hline & 80 89 & $27(31.8)$ & 32 (39.5) & & \\
\hline & 90 100 & 37 (43.5) & $22(27.2)$ & & \\
\hline \multirow{4}{*}{$\begin{array}{l}\text { b) How high is the chance that the women will become } \\
\text { pregnant if she is } 35 \sim 40 \text { years old? }\end{array}$} & $0 \sim 49$ & $12(14.1)$ & $27(33.3)$ & \multirow[t]{4}{*}{11.44} & \multirow[t]{4}{*}{.010} \\
\hline & $50 \sim 59^{\dagger}$ & 18 (21.2) & $21(25.9)$ & & \\
\hline & $60 \sim 69$ & $34(40.0)$ & $21(25.9)$ & & \\
\hline & 70 100 & $21(24.7)$ & 12 (14.9) & & \\
\hline \multirow[t]{4}{*}{ How many couples in Korea are involuntarily childless? } & $0 \sim 4$ & $1(1.2)$ & $3(3.7)$ & \multirow[t]{4}{*}{6.59} & \multirow[t]{4}{*}{.086} \\
\hline & $5 \sim 9$ & $9(10.6)$ & $17(21.0)$ & & \\
\hline & $10 \sim 19^{\dagger}$ & $60(70.6)$ & $54(66.7)$ & & \\
\hline & $20 \sim 90$ & $15(17.6)$ & $7(8.6)$ & & \\
\hline \multirow{4}{*}{$\begin{array}{l}\text { For couples that undergo treatment with IVF - what is } \\
\text { their chance, on average, of having a child after one } \\
\text { round of treatment? }\end{array}$} & $0 \sim 19$ & 16 (18.9) & $15(18.5)$ & \multirow[t]{4}{*}{1.71} & .635 \\
\hline & 20 29 & $20(23.5)$ & $26(32.1)$ & & \\
\hline & $30 \sim 39^{\dagger}$ & $38(44.7)$ & $30(37.0)$ & & \\
\hline & $40 \sim 100$ & 11 (12.9) & $10(12.4)$ & & \\
\hline
\end{tabular}

${ }^{*}$ Missing data were not included; ${ }^{\dagger}$ The category that contains the correct answer according to the published data by Centers for Disease Control and Prevention (2016); IVF=In vitro fertilization.

less, both genders incorrectly recognized the age at which female fertility begins to drop as older than 30 years old $(98.8 \%$ for women and $95.1 \%$ for men). Female students were more optimistic about the pregnancy rate, such as considering there to be more than a $60 \%$ possibility for females aged between 35 and 40 years old to become pregnant, than male students (64.7\% for women and $40.8 \%$ for men), and the difference between the groups was significant $\left(x^{2}=11.44, p=.010\right)$. Using open-ended questions, participants thought that the reasons for decrease in man fertility might include smoking, drinking, irregular diet, lack of exercise, stress, genetic disorders, overexposure to electronic devices, lack of sleep, and illness.

\section{DISCUSSION}

This study was conducted to shed light on intentions and attitudes towards parenthood and awareness of fertility issues among Korean female and male university students. In this study, nearly $44 \%$ of participants had a dating partner, while more than $72 \%$ planned to become parents. The number of those who planned to become parents is lower than that reported in other countries, such as the United States (US) at 89\% [13] and Denmark at 93\%[14]. Although female and male students thought that they would like to have a baby in the near future, they showed a lack of fertility awareness and low scores for presumed behaviors in the case of infertility. 
In this study, the desired number of children was two, which fits the recommendation based on the TFR that suggests that having two children is ideal to keep the national population steady. However, the actual birth rate in Korea was reported to be 1.05 in 2017, and decreased below 1.05 in 2019 [17]. This decrease in childbirth rate is similar to that in other developed countries despite the increased household income [21]. However, the number of desired children reported in this study is lower than has been reported by studies in the US and Denmark, according to which more than $85 \%$ of participants wanted to have two or three children $[13,14]$.

Compared to male students, female students were less likely to think that having children is important in their lives. Similarly, in another Korean study conducted by Lee [5], a lack of intention to become a parent was more common in female students than in male students. The opposite trend was reported in other studies in the US and Sweden [12,13]. Although there was no significant difference, male students were more likely to pursue IVF than female students, which is similar to what has been reported in other studies in Hong Kong and the US $[13,15]$. The higher value of having children and a greater willingness to try IVF observed in man participants might be specifically related to Korean culture. In Korea, procreation is linked to the expansion and preservation of the lineage and is emphasized in Confucianism, which is deeply rooted in Korean society [16].

We need to consider what makes young people decide to have children in the near future. The overwhelming majority (88.2\%) of female students reported that combining work with having children would impact their decision to pursue parenthood, compared to $74.1 \%$ of male students who felt the same. In Korean culture, married women are the primary caregivers for their children and spend more time with their children based on Confucian traditional gender roles [16]. Approximately half of woman students considered having access to childcare to be an important condition for parenthood, compared to just one-third of man students. Beets [22] explained that women's involvement in work has increased but men's duties and household roles have not changed much. Korean studies among college students suggest that the value of marriage has changed as society has changed, but partial gender inequality and the distinction between woman and man's roles still follows a paternalistic approach [23,24]. This could serve as a barrier to developing intentions to become a parent. In addition, Choi and Park [25] suggested that the financial burden combined with a woman's role in household management, including household chores or parenting, might interfere with the desire to have a child in the near future. The findings demonstrated that young people consider their freedom and right to make decisions to be important to their qual- ity of life, while social structures, such as family resources to provide care for their children, were insufficient to encourage them to marry and have a child.

The life impact of parenthood includes both positive and negative aspects. As a negative life impact, one-third of female students strongly agreed that they would have less time to devote to work and a career and a poorer status in the labor market. In contrast, fewer than one-fifth of male students answered that they would have less time to devote to work and career and a poorer status in the labor market. This result suggests that women's careers and lives are more impacted by parenthood than those of men. Therefore, it is necessary to provide possible resources or to develop policies for women so that parenthood does not hinder their pursuit of a career or interests. Furthermore, changes in perceptions of the roles of fathers or mothers in parenthood are necessary.

Nonetheless, positive expectations were found regarding the life impact of parenthood. Although both genders considered that parenthood would be a new interest and meaningful in their lives, there was a gender discrepancy, whereby male students considered parenthood to be more impactful on their lives than female students. To make parenthood as enjoyable a life experience as possible, society might need to provide supportive resources. At present, in order to create a more conducive atmosphere for childbearing, the Korean government has created policies and devoted financial resources such as providing support during pregnancy, medical assistance for infertile couples, childcare services, and tax incentives [26]. However, to fill the gap between the current policy and actual needs for couples, we need to identify how practically helpful these policy efforts are for married couples. As part of such efforts, we need to provide education for young adults to improve their awareness of fertility and to encourage them to consider their marriage and childbearing plans in advance.

Different levels of fertility awareness were found by gender. Woman students were more likely to overestimate female fertility than man students. In this study, a significant lack of awareness regarding fertility issues was found, which is similar to previous studies in Sweden, the US, and Hong Kong $[12,13,27]$. Differences between young adults' perceptions of fertility and their actual fertility could create childlessness in the near future regardless of their childbearing plans [13]. According to a literature review on the decline of male fertility, risk factors are closely associated with increase in age, unhealthy lifestyles, and environmental factors [27]. Unhealthy lifestyle factors include high-fat diets, high caffeine-content energy drinks, lack of exercise, high scrotal temperature, and life stressors from occupation or life events [27]. If young adult males consider these facts and modify their lifestyles in ad- 
vance, it would be beneficial for maintaining their fertility.

These research findings can provide a basis for forming policies on childbearing and justification for providing greater resources for young adults. When providing education on sexual health for young adults, it is important to provide accurate knowledge about fertility and information on how to maintain healthy lifestyles to maintain their fertility. Doing so empowers young adults to decide whether to pursue parenthood armed with various perspectives based on their rights and beliefs, while also considering their fertility based on age. Beyond parenthood plans, plans for childbearing are affected by choosing the right partner [13]. In Korea, finding a job is becoming increasingly difficult for young adults. As a result, young adults are striving to increase their capacity to procure a job in a competitive situation that might interfere with finding a life partner and forming childbearing plans.

The findings from this study should be interpreted with caution. We included Korean students from five different universities, with the specific goal of obtaining information on Korean young adults' attitudes towards parenthood. However, it might be difficult to generalize these results to average Korean university students, or to those of other Asian countries. In this study, some participants indicated that they were too young to consider becoming a parent. Therefore, future studies should adequately observe graduate students or employed single women and men in their early 30 s to better understand their perceptions of parenthood since their age would closely correspond to the average marriage or childbearing age, considering their career(s).

\section{CONCLUSION}

The findings of this study show that female and male university students lacked sufficient awareness of fertility. Male students tended to consider parenthood as being less impactful on their lives and careers, whereas female students considered it to more negatively impact their lives. Although becoming a parent is an individual decision, the government provides a supportive environment for childbearing to allow potential parents to make a choice about becoming a parent. When health educators provide education about sexual health, fertility awareness needs to be included and accurate information regarding fertility should be provided. This would give young adults the opportunity to consider this issue at an earlier age before they are too old to have children.

\section{Conflict of interest}

No existing or potential conflict of interest relevant to this article was reported.

\section{REFERENCES}

1. OECD. Education at a glance 2018: OECD Indicators. 2018: OECD; Paris. https://doi.org/10.1787/eag-2018-en

2. Sobotka T. Post-transitional fertility: The role of childbearing postponement in fueling the shift to low and unstable fertility levels. Journal of Biosocial Science. 2017;49(S1):S20-S45. https://doi.org/10.1017/S0021932017000323

3. Statistics Korea. 2018 Annual report on live births and deaths statistics [Internet]. Daejeon: Statistics Korea; 2019 [cited 2019 December 23]. Available from: http://kostat.go.kr/portal/eng/pressReleases/8/10/index.board

4. Brauner-Otto SR, Geist C. Uncertainty, doubts, and delays: Economic circumstances and childbearing expectations among emerging adults. Journal of Family Economic Issues. 2018;39(1):88-102. https://doi.org/10.1007/s10834-017-9548-1

5. Lee YJ. A study of the parenthood motivation, perceptions of becoming a parent, and confidence about parental roles of university students. Korea Journal of Child Care and Education. 2015;92:118.

6. Kim K. The changing role of employment status in marriage formation among young Korean adults. Demographic Research. 2017;36(5):145-172. https://doi.org/10.4054/DemRes.2017.36.5

7. Song JE, Ahn JA, Lee SK, Roh EH. Factors related to low birth rate among married women in Korea. PLoS One. 2018;13(3):e0194597. https://doi.org/10.1371/journal.pone.0194597

8. Yoon SY. The influence of a supportive environment for families on women's fertility intentions and behavior in South Korea. Demographic Research. 2017;36(7):227-254. https://doi.org/10.4054/DemRes.2017.36.7

9. Schwab K, Samans R, Zahidi S, Leopold TA, Ratcheva V, Hausmann R, et al. Insight report: The global gender gap report 2017 [Internet]. Geneva: World Economic Forum; 2017 [cited 2019 November 30]. Available from: https://www.weforum.org/reports/the-global-gender-gap-repo rt-2017

10. Stoop D, Cobo A, Silber S. Fertility preservation for age-related fertility decline. The Lancet. 2014;384(9950):1311-1319. https://doi.org/10.1016/S0140-6736(14)61261-7

11. Balasch J. Ageing and infertility: An overview. Gynecological Endocrinology. 2010;26(12):855-860. https://doi.org/10.3109/09513590.2010.501889

12. Lampic C, Svanberg AS, Karlström P, Tydén T. Fertility awareness, intentions concerning childbearing, and attitudes towards parenthood among female and male academics. Human Reproduction. 2006;21(2):558-564. https://doi.org/10.1093/humrep/dei367

13. Peterson BD, Pirritano M, Tucker L, Lampic C. Fertility awareness and parenting attitudes among American male and female undergraduate university students. Human Reproduction. 2012;27(5): 1375-1382. https://doi.org/10.1093/humrep/des011 
14. Sørensen NO, Marcussen S, Backhausen MG, Juhl M, Schmidt L, Tydén T, et al. Fertility awareness and attitudes towards parenthood among Danish university college students. Reproductive Health. 2016;13(1):146. https://doi.org/10.1186/s12978-016-0258-1

15. Chan CHY, Chan THY, Peterson BD, Lampic C, Tam MYJ. Intentions and attitudes towards parenthood and fertility awareness among Chinese university students in Hong Kong: A comparison with Western samples. Human Reproduction. 2014;30(2):364-372. https://doi.org/10.1093/humrep/deu324

16. Lee Y. Women workforce in the Korean context. International Review of Management and Marketing. 2017;7(1):403-412.

17. Statistics Korea. 2018 Marriage and divorce statistics [Internet]. Daejeon: Statistics Korea; 2019 [cited 2019 December 17]. Available from:

http://kostat.go.kr/portal/eng/pressReleases/8/11/index.board

18. DeVellis RF. Scale development: Theory and applications. 4 th ed. London: Sage Publications; 2016.

19. Shi J, Mo X, Sun Z. Content validity index in scale development. Journal of Central South University (Medical Sciences). 2012;37(2): 152-155. https://doi.org/10.3969/j.issn.1672-7347.2012.02.007

20. Centers for Disease Control and Prevention. Assisted reproductive technology (ART) [Internet]. Washington, D. C.: Center for Disease Control and Prevention; 2019 [cited 2019 December 14]. Available from: https://www.cdc.gov/art/whatis.html

21. Doepke M. Gary Becker on the quantity and quality of children. Journal of Demographic Economics. 2015;81(1):59-66. https://doi.org/10.1017/dem.2014.8

22. Beets G. Baby booms and busts: Waves in fertility patterns. Anthropologischer Anzeiger. 2009;67(4):461-472.

https://doi.org/10.1127/0003-5548/2009/0037

23. Chung MR, Chang YH. A study on the conception of the values of marriage, having child and job of university students and it's variables. Educational Research. 2007;41:91-108.

24. Shin S, Hwang E, Kim KH. Development of educational model for establishment of university students' healthy views on marriage and child-caring. Korean Journal of Women Health Nursing. 2010; 11(1):71-84

25. Choi Y, Park Y. Analysis of perceptions of marriage and birth and the pattern of low birth rate. Citizen and Humanities. 2019;36:101-137.

26. Fleckenstein T, Lee SC. The politics of postindustrial social policy: Family policy reforms in Britain, Germany, South Korea, and Sweden. Comparative Political Studies. 2014;47(4):601-630. https://doi.org/10.1177/0010414012451564

27. Ilacqua A, Izzo G, Emerenziani GP, Baldari C, Aversa A. Lifestyle and fertility: The influence of stress and quality of life on male fertility. Reproductive Biology and Endocrinology. 2018;16:115. https://doi.org/10.1186/s12958-018-0436-9 